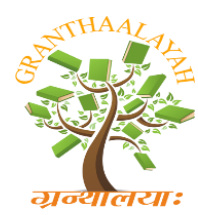

INTERNATIONAL JOURNAL OF RESEARCH GRANTHAALAYAH

A knowledge Repository

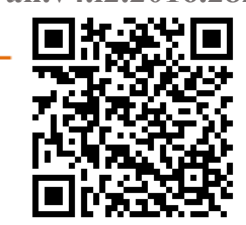

Management

\title{
THE INFLUENCES OF MACRO-ECONOMIC FACTORS ON CAPITAL MARKET PERFARMANCE IN PAKISTAN
}

\author{
Muhammad Abdul Kabeer ${ }^{1}$, Amir Iqbal ${ }^{2}$, Rabia Najaf ${ }^{3}$, Khakan Najaf ${ }^{4}$ \\ 1, 2, 3,4 Department of Accounting \& Finance, University of Lahore, Islamabad Campus, \\ PAKISTAN
}

\begin{abstract}
The key determination of the present research is to examine the impact of selected major variables on stock return of the Pakistani emerging capital market Karachi Stock Exchange. The researches display that capital market is inclined by transform in major economic variables. This study observes impact of three major economic variables i.e. foreign direct investment, foreign exchange rate and inflation at Karachi stock exchange. The monthly data of ten years practice in this study. To reach the objectives, study uses the Ordinary Least Square (OLS) to estimate the correlation and regression model. The Durbin-Watson statistics 1.90 value indication that there are no serial correlations issues in study. And results show that significant negative impact of inflation and Foreign exchange rate \&foreign direct investment negative insignificant impact on $\mathrm{KSE}$ dependent variable. And overall model good fit by probability of F-statistics which less than $5 \%$.
\end{abstract}

Keywords:

Capital market returns, macro-economic variables, OLS.

Cite This Article: Muhammad Abdul Kabeer, Amir Iqbal, Rabia Najaf, and Khakan Najaf, "THE INFLUENCES OF MACRO-ECONOMIC FACTORS ON CAPITAL MARKET PERFARMANCE IN PAKISTAN" International Journal of Research - Granthaalayah, Vol. 4, No. 2 (2016): 139-150.

\section{INTRODUCTION}

In capital markets, the stock price determent by micro factors in short \& long run e.g. financial \& liquidity position of firm, profit or loss declare and dividend announcement etc. But also, influence on stock returns by some national factors i.e. stock market regulation \& tax impose by national government. And some major economic factors furthermore influence i.e. foreign direct investment, inflation, industrial production, interest rate, savings, foreign exchange reserves, gross domestic product, exchange rate, money supply, imports \& exports of goods \& services and oil \& gold prices fluctuation in international markets, used by various researchers. There are one of the most important role of capital market is to act upon as moderator along with investor and borrowers opportunities for investment. In short-term and long run the securities are traded 
of listed companies in capital market and as well affected by micro and major economic factors. These factor representations study the sensitivity of an equity \&debenture return as a role of one or more factors. The capital market and a mixture of variables are directly related with each one other.

\section{OBJECTIVES OF THE STUDY}

The specific purpose of this research is following objectives:

i) To look at the macro-economic factors.

ii) To find are there any correlation exist between stock return and major-economic factors.

iii) To study the significant impact of macro-economic factors on stock return.

\section{REVIEW OF EMPIRICAL STUDIES}

A lot of consequences obtained in the rest of world by researcher used different statistical techniques to affiliation between macro-economic factor and stock return in developed \& emerging capital markets and come across impact of these variables on stock market enlargement. The research paper's contribute from poles apart from emerging countries are as follows.

Abbas, A., Tahir, S, H,.\& Raza, S,. (2014) empirically investigated relationship between five Independent Variables namely Inflation, exchange rate, Gross Domestic Product, gold prices \& T-bills rate and Dependent Variable Karachi Stock Exchange 100 index. The study used data on monthly base a period from January 2002 to December 2012. The authors employed Regression and Pearson correlation method find that Dependent variable (DV) negatively co-related with all independent variables (IV), insignificant positive relationship between exchange rate (ER) and stock return, the relationship between inflation rate (IR) and stock return is negative insignificant, Treasury bills (T-bills) is insignificant negatively co-related with Stock Return, Gold prices (GP) is negatively insignificant and Gross Domestic Product has positively insignificant relation with Stock Return in Pakistan.

R. B. Khodaparasti (2014) examined how exchange rates, inflation, industrial index and M1 as Independent Variables on Tehran Stock Index (TSI) Dependent Variables affect. The authors used secondary data base a period from 2007- 2011. Researcher used Pearson correlation and ANOVA method get that exchange rates and industrial index have more effect on the stock return than inflation and Money supply in Iran.

Ouma, W, N,.\& Muriu, P,. (2014) investigated the impact of macro-economic variables on stock prices. The researchers employed three Independent Variables namely Money Supply, exchange rates and inflation to be tested the dependent Variable Nairobi Stock Exchange (NSE 20). The study worked data a period from January 2003 to January 2013 on monthly base. Applied technique the classical regression model, best linear unbiased estimates (BLUE), Augment Dickey-Fuller (ADF) and find result that interest rates (IR), there are a significant relation between stock returns (SR) and macroeconomic variables, Money supply (M1) and inflation (IR) are found to be significant relation of the Stock returns. Exchange rates (ER) have a negative impact on stock returns, while interest rates (IR) no relation long-term return. And there is 
positive significant relationship between Money supply (M2) on stock returns and also negative \& significant impact of exchange rate on stock returns, while a positive impact of inflation on stock returns. There is no impact of Interest rates (IR) on stock returns exist in Kenya.

Wasseja, M. M,.Njoroge, E,.\&Mwenda, S, N,. (2015) analyze the Causal Relationship between Macroeconomic Variables and Stock Prices in Kenya, used Augmented-Dickey Fuller Unit Root Test, Johansen co-integration test, Regression, Granger-causality test and vector autoregressive (VAR) model. These five Independent Variables are namely Treasury bill, Inflation rate, money supply, Real Exchange Rate and Gross Domestic Product and dependent Variable Nairobi Stock Exchange (NSE 20). The study worked historically annual data a period from 1980 to 2012. Researchers used technique Augmented-Dickey Fuller Unit Root Test, Johansen co-integration test, Regression, Granger-causality test and vector autoregressive (VAR) model. The result are that macroeconomic variables no significant effect on stock prices except for inflation rate; exchange rate and change in stock prices also an insignificant factor explaining part of the movement in the macroeconomic variables except for market interest rates. In regression analysis all the macroeconomic variables are jointly significant in explaining the variations in stock prices. The causality between macroeconomic variables and stock prices runs entirely in one direction from inflation rate (IR) and exchange rate (ER) to stock prices (SP) and from stock prices (SP) to market interest rates (IR) in Kenya.

NAIK, P, K,.\& PADHI, P,. (2012) have argued that stock return should be affected by five Independent Variables namely industrial production index (IP), wholesale price index (inflation), money supply (M3), treasury bills rates (t-bills) and exchange rates (ER) on Bombay Stock Exchange (BSE). Study collected monthly data a period from April 1994 to June 2011. Result found by used Johansen's co-integration and vector error correction model that the Indian stock market index formed significant long-run relation with three out of five macroeconomic variables tested. In the long-run, the stock prices are positively related to money supply (M3) and real economic activity represented by industrial production index (IP). Inflation has found to be negatively related to stock price index, the short term interest rate (IR), as proxies by three month government treasury bills (T-bills) and the real effective exchange rate (ER) are not turning out to be the significant determinant of stock prices. In India, the interest rate (IR) does Granger cause to stock prices in the long run but the co-integration results do not show its significant impact on stock prices although the coefficient is negative in India.

Alam, Z, \& Rashid, K,. (2014) explore the interaction between Independent Variables namely inflation, industrial production, money supply, exchange rate and interest rate dependent Variable Karachi Stock Exchange 100 index. A period of secondary data collected from 2001 to 2011 on monthly base. Researchers find out result by used Johnson Co-integration test, Augmented Dickey Fuller (ADF) Unit Root Test, Phillip Perron (PP) tests and Autoregressive Conditional Heteroskedasticity Lagrange Multiplier (ARCH LM) test, that there is an impact of macroeconomic indicators on the Karachi stock market (DV) on consumer price index, money supply, exchange rates and interest rates negatively connected with the stock returns, while the industrial production index positively connected with the stock returns. All the variables were significantly connected to stock market returns except inflation in Pakistan. 
Osamwonyi, I, O, \& Michael, C, I,. (2014) collected annual data a period from 1990-2013 found a positive relationship between Independent Variables namely gross domestic product, interest rate, exchange rate and inflation and dependent Variable Return On Equity (ROE) Listed commercial banks profitability in Nigeria. Researchers practical the Regression technique found a positive relationship of GDP with return on equity (ROE), Interest rate and inflation rate have a negative relationship with return on equity (ROE). GDP significant positive effect on Return on equity (ROE), while interest rate have a significant negative effect on return on equity(ROE) but inflation is not significant at all levels of significance in Nigeria.

Raza, A,. Iqbal, N,. Ahmed, Z,. Ahmed, M,.\& Ahmed, T,. (2012) study the relation between stock return and macro-economic Independent Variables namely Foreign Direct Investment, Domestic Savings, Exchange Rate and Inflation rate and Karachi Stock Exchange 100 index dependent Variable. The study found result a period worked on 1988-2009, that FDI and Domestic savings are positive significant impact on Stock market development. And exchange rate negative significant impact, while inflation insignificant impact over stock market development in Pakistan.

Ahmad, A, U,. Abdullah, A,.Abdullahi, A, T,. Aziz, U, A,.\& Muhammad (2015) identified relation between two Independent Variables namely Per capita income \& inflation with dependent Variable Nigerian Stock Market (NSE). Study conducted annual data from 1970 to 2013. Researcher pertain Zivot-Andrews Unit Root Test, F-Bound Co-integration and Toda and Yamamoto Causality tests. Results found that the variables were non-stationary at levels but were stationary after first differencing. Co-integration established the existent of co-integration amongst all the variables. There is significant positive impact of Structural break (1996) on the Nigerian stock market returns in both short-run and the long-run. The Gross domestic per capita income a Key provider to increasing stock market returns and also positive impact of Gross domestic per capita income and inflation on stock market returns in Nigeria.

Issahaku, H,.Ustarz Y,.\&Domanban, P, B,. (2013) examines the association between five Independent Variables namely Exchange rate, Consumer Price Index (inflation), treasury-bill rate, money supply \& FDI and Ghana Stock Exchange (GSE) as a dependent Variable. The study worked period from January 1995 to December 2010 and collected data on monthly base with used technique Unit Root Test, Co-integration and Granger Causality Test. The researchers found the result that in long run, a significant relationship among stock returns and inflation, money supply and FDI. Also, in the short term significant relationship among stock returns and interest rate, inflation and money supply. There are insignificant relationships between stock returns and FDI in short-run. And a causal relationship existing between in inflation and exchange rate to stock returns has been established in study. Also, a causal relationships appeared from stock returns to FDI, interest rate, and money supply Exists in Ghana.

Yunus, M, M,.Mahyideen J, M,.\&Saidon, R,. (2014) evaluate short-term association between Independent Variables and dependent Variable. Authors used five Independent Variables namely money supply, industrial production, exchange rate, interest rates \& foreign reserves with dependent Variable Malaysia stock market. Study found result with techniques used Johansen co-integration test and vector error correction model (VECM) that foreign reserves, real exchange rate and industrial production exhibited the significant response to the changes in stock 
prices in the short run, while money supply and interest rates did not indicate the significant responses to stock prices. A period of data collected on monthly base from January 1980 to November 2007.

Hasanzadeh, A,.\&Kianvand, M,. (2012) study the relationship between macro-economic variables namely gross domestic product, nominal effective exchange rate, money supply, gold coin price and investment in housing sector, dependent Variable Tehran Stock Index (TSI). Researchers worked on quarterly base a period from January 1996 to January 2008. Study used process Co-integration and Vector Error Correction Method (VECM) and found result that Stock prices show significantly negative relation with nominal effective exchange rate and the relationship between stock price and money supply is found significantly positive. With an increase in gross domestic product (GDP) that is positive effect \& increases stock prices. And gold coin \& housing division act as substitutes for stock market in Iran.

Menike, \& L.M.C.S. (2006) analyzed the relationship between Independent Variables namely exchange rate, inflation rate, money supply, \& interest rate and dependent Variable Sri Lankan Stock Market. Authors worked on monthly data from September 1991 to December 2002. And applied multivariate regression method and try to result that most significant variable the exchange rate is mainly negative to stock prices, a strong negative relation exist the between stock prices and inflation rate, Stock prices react negatively to Treasury Bill rate. The lagged money supply variables become visible to have a negative outcome on stock prices in Sri Lankan Stock market.

Nijam, HM,. Ismail, SMM,.\&Musthafa, AMM,. (2015) described a relationship between five Independent Variables namely Gross domestic product (GDP), Inflation proxy by wholesale price index (WPI), Interest rate (IR), Balance of payment (BP) \& Exchange rate (ER) and Colombo stock exchange as a dependent Variable. Researchers applied practice on Correlation and Multiple Regression techniques on a period from 1980 to 2011. Outcome of study that stock market significantly positively relates to Gross domestic product (GDP), Exchange Rate (ER) and Interest Rate (IR) while it negatively relates to inflation. Insignificant impact of Balance of payment (BP) found to be deterred the stock market performance in Sri Lanka.

Khan, M, S,. (2014) studied the relation between Independent Variables namely exchange rate, interest rate, inflation rate \& GDP (Gross domestic product) growth rate and dependent variable Karachi Stock Exchange 100 index. Study used data from 1992 to 2011 with constructive techniques Pearson's correlation coefficient and multiple regression models found result about exchange rate, inflation \& GDP growth rate show in a positive straight line correlation with stock prices of dependent variable. And interest rate show opposite \& depressing correlation with stock prices of KSE-100 index. And exchange rate \& inflation are statistically significant, while interest rate \& GDP growth rate is statistically insignificant. There are relationship survive between exchange rate \& stock prices of KSE-100 index show strong positive correlation with stock prices and also statistically very significant in Pakistan.

Venkatraja, B,. (2014) investigated association between five Independent variables namely the real economic output (Index of industrial production), foreign institutional investment, inflation, gold price \& exchange rate and Bombay Stock Exchange (BSE) as a dependent Variable. Author 
collocated data from April 2010- June 2014 on monthly base. The study practical multiple regression and found that Inflation, inflow of foreign institutional investment, exchange rate \& gold price positive influence impact on the Indian stock market performance significantly, While, an increase in gold price is found causing crash in Indian stock market.

Singh, P,. (2014) scrutinized relationship about macro-economic factors. The study used Index of Industrial Production (IIP), Wholesale Price Index (WPI), Money Supply (M3), 91 days treasury bills as proxy for Interest Rates (IR), Trade Deficit (TD), Foreign Institutional Investment (FII), Exchange rate (ER), Crude Oil Price (CP) \& Gold Price (GP) nine Independent Variables and Bombay Stock Exchange (BSE) as a dependent Variable. Researcher collected data from January 2011 to December 2012 on monthly base. The realistic technique correlation, multivariate stepwise regression analysis and Granger causality test to originate a Significant impact of gold, money supply, exchange rates \& foreign institutional investors on the Indian stock market, Another unidirectional causality is from money supply to S\&P CNX Nifty which signifies the pressure of variable on the Indian stock market.

Momani, G, F,.\&Alsharari M, A,. (2012) also studied the relationship between Amman Stock Exchange as a dependent Variable and four Independent Variables namely Annual Gross National Product (GNP), Annual Money Supply, Annual Interest Rates on the Long-term Deposits and Annual Industrial Production Index. Researchers used data a period from 1992 to 2010 and practical multiple regressions (stepwise method). Result show that a relation create with statistical significance between the all independent and dependent variables. The interest rates variable has an enormous influence on Amman Stock Exchange.

Ali, R,.Haq, M, A,.\&Ullah, S,. (2015) studied the impact of macro-economic variables on Karachi Stock Exchange 100 index dependent variable. The researchers investigated the relationship with respect to Gross Domestic Saving (GDS), Money Supply (MS) and Foreign Remittances (FR) as Independent Variables. Study worked data on annual base start period from 1973 to 2012. Researchers applied Philips and Perron Test and Auto Regressive Distributed Lag (ARDL) to co-integration technique. The ARDL to Co-integration results proved that Gross domestic savings, money supply have positively force on stock market expansion in Pakistan in both short run and long run that are consistent. Foreign remittances have an insignificant effect on stock market development in short run, while in long run the researchers found no any effect on stock market in Pakistan.

Nkechukwu, G,.Onyeagba J,.\&Okoh J,. (2013) examined the relationship between two Independent Variables gross domestic product (GDP) \& broad money supply (M2) and dependent Variable Nigerian stock market. Researchers worked annually data start from 19802012. The study used statistical tools the Augmented-Dickey Fuller Unit root test, Co-integration analysis, Normalized Co-integrating Vectors Test, vector error correction model (VECM), Granger-causality tests. A significant found by researchers in the co-integrating vectors indicated that gross domestic product has long-run negative effect on stock market prices contrary to the a priori expectation Money supply has long-run positive effect on stock market prices, Which it is consistent with the a priori expectation. However, the results of the vector error correction model show that both gross domestic product \& money supply (M2) have insignificant positive effect on stock market prices in Nigeria. 
Hosseini, S, M,. Ahmad, Z,.\& Lai, Y, W,. (2011) empirically investigated the relationship among four Independent Variables namely crude oil price (COP), money supply (M2), industrial production (IP) \& inflation rate (IR) and dependent Variables Bombay Stock Exchange (BSE) and Shanghai Stock Exchange index (SSE). The study worked on data a period from January 1999 to January 2009 monthly base. The researcher worked statistical technique simple linear regression model, Multivariate Co-integration Test, Vector Error Correction Model (VECM) and Augmented-Dickey Fuller Unit Root Test. The researcher's Result show:

China: In the long-run, the impact of increases in crude oil price in China is constructive force, also Money supply in China it encouraging impact. In china the industrial production (IP) negative. Also in effect of increases in inflation on this stock positive in China. The simultaneous impact of money supply exist Chinese stock market positive. The simultaneous effect of inflation on current Chinese stock index (SSE) positive and significant but this effect lagged one month though positive significant.

India: In the long run, the impact of increases in crude oil price in India this effect is negative, money supply the impact on Indian stock market is negative. In India the effect of increases in inflation stock return positive. In the short run, the simultaneous effect of crude oil price positive in India. The simultaneous impacts of money supply in India it negatively. And the simultaneous effect negative insignificant. However, the lagged effects negative and significant in India.

Sharma, G, D,.\&Mahendru, M,. (2010) found the relationship between four Independent Variables namely inflation rate, foreign exchange reserve, exchange rate and gold price and dependent Variable Bombay Stock Exchange (BSE). Study examined weekly data a period from January 2008 to January 2009. The researchers used statistical multiple regression model. Result show that Independent variables exchange rate \& gold price have a significant relation with stock price, it give the impression to affect the entire stock price while inflation rate significant for only three of the twelve portfolios. Inflation rate \& gold price do not become visible to have any significant effect on stock returns. It means that inflation rate \& foreign exchange reserve don't influence the stock price.

Ahmad, A, U,. Abdullah, A,.Sulong Z,.\&Abdullahi, A, T,. (2015) identified the Causal Relationship between Stock Market Returns in Nigerian Stock Exchange as a dependent Variable and six Macroeconomic Independent Variables namely money supply, nominal effective exchange rate, short term treasury bills rate, foreign direct investment, gross domestic per capita income, and gross domestic saving. The researchers used statistics methods Autoregressive Distributive Lag (ARDL) and Vector Autoregressive Model (VAR) and found result that these all six variables have a long-run equilibrium relationship between them, although they may be in disequilibrium in the short-run used time period from 1984 to 2013.

Gay, R, D,.\& Jr,. (2008) conducted empirical research on exchange rate and oil price as an Independent Variables and stock markets of BRIC (Brazil, Russia, India and China) countries as a dependent Variable. Study effort on monthly data of BRIC (Brazil, Russia, India and China) countries from March 1999 to June 2006. Box-Jenkins ARIMA statistical model used and found the effect of exchange rate and oil price on the stock market return of Brazil, Russia, India, and China did not reveal a significant relationship, Although, the descriptive values of exchange rate, 
oil prices and the lagged stock market return were not significant in BRIC (Brazil, Russia, India and China) countries.

Akinlo, O, O,. (2015) analyzed effect of two Independent Variables foreign exchange reserves \& interest rate and dependent Variable Nigerian Stock Exchange. Study worked annual data a period from 1981 to 2011. Statistical technique unit root tests obtained using the AugmentedDickey Fuller and KPSS (Kwiatkowski-Phillips-Schmidt-Shin) tests the results show that foreign reserves had positive effect on stock exchange development. And Granger causality show that a bidirectional cooperative association be present between interest rates \& stock market development. In the same vein, there was a cooperative association between interest rate and external reserves in Nigeria.

Khan, K,.\& Ahmed, I,. (2015) established the relation between macro-economic variables of national Imports \& Exports of Goods \& Services as an Independent Variables and Karachi Stock Exchange 100 index as a dependent Variable. Researchers worked on Quarterly data start a period from 2005 to 2009. Statistical Regression and Co-integration applied and found result that the Historically stock prices (SP) predicts the current fluctuation in stock prices (SP) and it predict the current fluctuation of National exports while there are no impact on current values of imports by the historically stock prices (SP) or historically stock prices are not predicting the current fluctuation in imports of Pakistan.

\section{DESIGN AND RESEARCH METHODOLOGY}

Definition of model:

The econometric model under study given the following equation:

$Y=\alpha+B_{1} X_{1}+B_{2} X_{2}+B_{3} X_{3}+B_{4} X_{4}+B_{5} X_{5}+\varepsilon$

Where:

$\mathrm{Y}$ is dependent variable, " $\alpha$ " is $\mathrm{y}$ - intercept and $\mathrm{x} 1, \mathrm{x} 2, \mathrm{x} 3, \mathrm{x} 4$, and $\mathrm{x} 5$ are independent variables while $\varepsilon$ is random error term.

Implementation of the econometric Model:

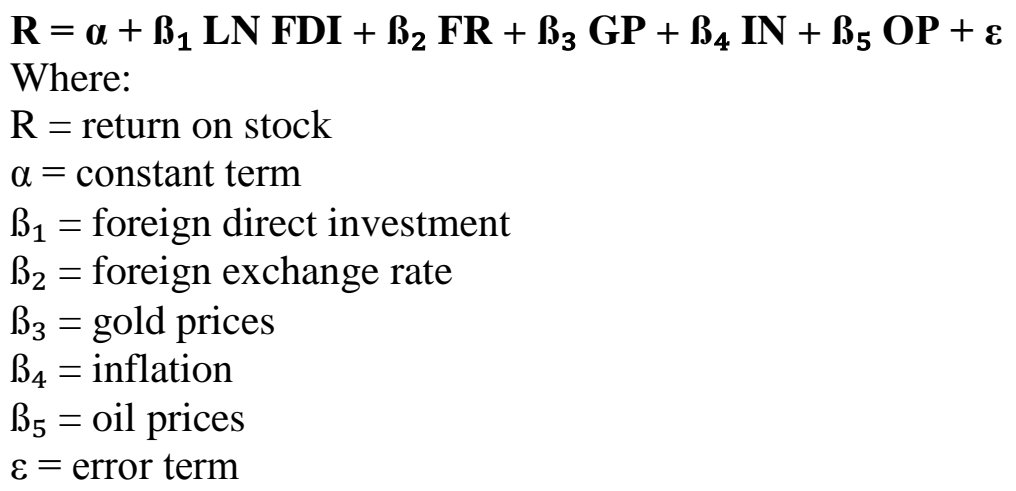




\section{RESEARCH METHODOLOGY}

The study has been conducted the secondary data to find the relationship between macroeconomic variables and stock return. In this study,econometric model Ordinary Least Square (OLS) to estimate the particular circumstances and in relation to which other variable quantities may be expressed.Data analysis performed on MS Excel and E-views statistical software. The regression technique makes use of by OLS to identify the significance \&direction of relations between Karachi Stock Exchange and major economic factors.

\section{Stock return:}

Karachi stock exchange 100 index return chosen for the study based on accessibility and also reliability of data. Stock prices are obtained from Karachi stock Exchange official site and experiential on monthly basis stock prices in the period from November 2005 to October 2015. The stock return is calculated as the monthly change in the stock price by the following formula: $\mathrm{R}(\mathrm{t})=(\mathrm{P} 1 / \mathrm{P} 0)-1$

Where $\mathrm{R}(\mathrm{t})$ the stock price in month $\mathrm{t}$ and $\mathrm{P} 1$ is current month stock price and P0 previous month stock price.

\section{Foreign direct investment:}

Foreign direct investment is eminent from assortment foreign investment, a passive investment in the securities of a different country such as public stocks and bonds. Foreign direct investment data collected from State Bank of Pakistan official site on monthly base start a period from November 2005 to October 2015. FDI calculated as the monthly value by the following formula: FDI $(\mathrm{t})=\mathrm{LN}(\mathrm{t})$

Where FDI ( $\mathrm{t}$ ) the value at month $\mathrm{t}$ and $\mathrm{LN}(\mathrm{t})$ is natural logarithm in MS excel in month ( $\mathrm{t}$ ) of FDI value.

\section{Foreign exchange rate:}

In term of finance, a foreign exchange rate, between two currencies is the rate at which one currency will be exchanged for another. Foreign exchange data obtained from State Bank of Pakistan official site and collected rate monthly base start a period from November 2005 to October 2015. Foreign exchange rate calculated as the monthly rate by the following formula: $\mathrm{FR}(\mathrm{t})=1 / \operatorname{USD}(\mathrm{t})$

Where FR $(\mathrm{t})$ foreign exchange rate month $\mathrm{t}$, and 1 divided by USD are equal to PKR value at month (t).

\section{Gold prices:}

All of the valuable metals, gold is the most accepted as an investment. Investors normally buy gold as a way of diversifying risk, particularly through the use of futures contracts and derivatives. The gold market is subject to conjecture $\&$ unpredictability as are other markets. Gold prices data collected from World Bank and monthly base start a period from November 2005 to October 2015. Gold price in Pakistan Rupee, 1 Troy per ounce (unit of mass (weight)) is equal to 31.1034 Grams (unit of mass in metric system) weight. Gold prices calculated as the monthly Value by the following formula:

$\mathrm{GP}(\mathrm{t})=\mathrm{LN}(\mathrm{t})$ 
Where GP ( $t$ ) the value at month $t$ and $\mathrm{LN}(\mathrm{t})$ is natural logarithm in MS excel in month ( $\mathrm{t}$ ) of the gold price.

\section{Inflation:}

Inflation, an increase in the general level of prices reduces the actual value of money, in this manner reducing the expected cash inflow from a benefit, exceptions being inflation indexed securities. The calculation of the inflation rate is the consumer price index (CPI), obtained from the State Bank of Pakistan official site. The twelve-monthly (YOY) change in CPI is given by the following formula:

$\mathrm{I}(\mathrm{t})=\mathrm{CPI}(\mathrm{t})-\mathrm{CPI}(\mathrm{t}-12)$

Where I ( $\mathrm{t}$ ) the annual change in CPI, that is, the inflation in month $\mathrm{t}, \mathrm{CPI}(\mathrm{t})$ is the CPI in month $\mathrm{t}$ and $\mathrm{CPI}(\mathrm{t}-12)$ is the CPI in the same month of the previous year time period.

\section{REFERENCES}

[1] Abbas, A., Tahir, S, H,.\& Raza, S,. (2014). Impact of Macroeconomic Variables on Stock Returns: Evidence from KSE-100 Index of Pakistan, Research Journal of economics \& Business Studies, ISSN: 2251-1555, Volume: 03, Number: 7, pages 70-77.

[2] $R$. B. Khodaparasti (2014). The role of macroeconomic variables in the stock market in Iran, polish journal of management studies, Vol. 10, No 02, pages 54-64.

[3] Ouma, W, N,.\&Muriu, P,. (2014).The impact of macroeconomic variables on stock market returns in Kenya, International Journal of Business and Commerce, (ISSN: 22252436), Vol. 3, No.11, pages 01-31.

[4] Wasseja, M. M..Njoroge, E..\&Mwenda, S, N,. (2015). Investigation of the Granger Causal Relationship between Macroeconomic Variables and Stock Prices in Kenya, International Journal of Business and Economics Research, ISSN: 2328-7543, Vol. 4, No. 3, pages 98-108.

[5] NAIK, P, K,.\& PADHI, P,. (2012).The Impact of Macroeconomic Fundamentals on Stock Prices Revisited: Evidence from Indian Data, Eurasian Journal of Business and Economics, Vol. 5 Issue10, pages 25-44.

[6] Alam, Z, \& Rashid, K,. (2014). Time Series Analysis of the Relationship between Macroeconomic Factors and the Stock Market Returns in Pakistan, Journal of Yasar University, Vol. 9 Issue 36, pages 6261-6380.

[7] Osamwonyi, I, O, \& Michael, C, I,. (2014). The impact of macroeconomic variables on the profitability of listed commercial banks in Nigeria, European Journal of Accounting Auditing and Finance Research, Vol.2, No.10, pages 85-95.

[8] Raza, A,. Iqbal, N,. Ahmed, Z,. Ahmed, M..\& Ahmed, T,. (2012).The Role of FDI on Stock Market Development: The Case of Pakistan, Journal of Economics and Behavioral Studies, ISSN. 2220-6140, Vol. 4, No. 1, pages 26-33.

[9] Ahmad, A, U,. Abdullah, A,.Abdullahi, A, T,. Aziz, U, A,.\& Muhammad (2015). Stock Market Returns and Macroeconomic Variables in Nigeria: Testing for Dynamic Linkages with a Structural Break, Scholars Journal of Economics, Business and Management, ISSN 2348-8875, Vol. 2 No 8A, pages 816-828.

[10] Issahaku, H,.Ustarz Y,.\&Domanban, P, B,. (2013). Macroeconomic variables and stock market returns in Ghana: any causal link? Asian Economic and Financial Review, Vol. 3 No 8, pages 1044-1062. 
[11] Yunus, M, M,.Mahyideen J, M,.\&Saidon, R,. (2014).Influences of macroeconomic variables on stock prices in Malaysia, International Conference on Postgraduate Research, (e-ISBN 978-983-3048-98-4),pages No. 399-416.

[12] Hasanzadeh, A,.\&Kianvand, M,. (2012).The Impact of Macroeconomic Variables on Stock Prices: The Case of Tehran Stock Exchange, Money and Economy, Vol. 6, No. 2, Winter 2012, pages 171-190.

[13] Menike, \& L.M.C.S. (2006).The Effect of Macroeconomic Variables on Stock Prices in Emerging Sri Lankan Stock Market, Sabaragamuwa University Journal, vol. 6, no. 1, pages 50-67.

[14] Nijam, HM,. Ismail, SMM,.\&Musthafa, AMM,. (2015). The Impact of Macroeconomic Variables on Stock Market Performance; Evidence from Sri Lanka, Journal of Emerging Trends in Economics and Management Sciences, (ISSN: 2141-7024), Vol. 6, Issue 2, pages 151-157.

[15] Khan, M, S,. (2014). Macroeconomic Variables \& its Impact on KSE 100 Index, Universal Journal of Accounting and Finance, Vol. 2 Issue 2, pages 33-39,

[16] Venkatraja, B,. (2014). Impact of Macroeconomic Variables on Stock Market Performance in India: An Empirical Analysis, International Journal of Business Quantitative Economics and Applied Management Research, Vol.1, Issue 6, pages 71-85.

[17] Singh, P,. (2014).Indian stock market and macroeconomic factors in current scenario, International Journal of Research in Business Management, ISSN(P): 2347-4572, Vol. 2, Issue 11, pages 43-53.

[18] Momani, G, F,.\&Alsharari M, A,. (2012). Impact of Economic Factors on the Stock Prices at Amman Stock Market (1992-2010), International Journal of Economics and Finance, Vol. 4, Issue 1, pages 151-159.

[19] Ali, R..Haq, M, A..\&Ullah, S,. (2015). Macroeconomic Indicators and Stock Market Development, Developing Country Studies, ISSN 2224-607X, Vol.5, No.9, pages 139-149.

[20] Nkechukwu, G..Onyeagba J,.\&Okoh J,. (2013). Macroeconomic Variables and Stock Market Prices in Nigeria: A Co-integration and Vector Error Correction Model Tests, International Journal of Science and Research (IJSR), ISSN (Online): 2319-7064, Volume 4 Issue 6, pages 717-724.

[21] Hosseini, S, M,. Ahmad, Z,.\& Lai, Y, W,. (2011).The Role of Macroeconomic Variables on Stock Market Index in China and India, International Journal of Economics and Finance, Vol. 3, No. 6, pages 233-243.

[22] Sharma, G, D,.\&Mahendru, M,. (2010).Impact of macro-economic variables on stock prices in India, Global Journal of Management and Business Research, Vol. 10, Issue 7, pages 19-26.

[23] Ahmad, A, U,. Abdullah, A,.Sulong Z,.\&Abdullahi, A, T,. (2015). Causal Relationship between Stock Market Returns and Macroeconomic Variables in Nigeria, IOSR Journal of Humanities and Social Science, ISSN: 2279-0845, Volume 20, Issue 5, pages 74-96.

[24] Gay, R, D..\& Jr,. (2008). Effect Of Macroeconomic Variables On Stock Market Returns For Four Emerging Economies: Brazil, Russia, India, And China, International Business \& Economics Research Journal, Volume 7, Number 3, pages 1-8.

[25] Akinlo, O, O,. (2015).Impact of foreign exchange reserves on Nigerian Stock Exchange, International Journal of Business and Finance Research, ISSN: 1931-0269, Vol. 9, No. 2, pages 69-76. 
[26] Khan, K,.\& Ahmed, I,. (2015). Impact of Stock Prices on Macroeconomic Variables: Evidence from Pakistan, KASBIT Business Journal (KBJ), Vol. 8, No.1, pages 42-59.

[27] Economic data - Monetary statistics, State bank of Pakistan. Retrieved November 2015, http://www.sbp.org.pk/ecodata/index2.asp

[28] Country economic data of world economy, data - by country, world Development Indicators Retrieved November 2015,http://data.worldbank.org/country/pakistan. 